\title{
Does Perceived Corruption Moderate the Relationship Between Economic Factors and Tax Compliance? A Proposed Framework for Nigerian Small and Medium Enterprises
}

\author{
Augustine Ayuba* \\ *School of Accountancy, College of Business, Universiti Utara Malaysia, 06010 UUM Sintok, Kedah Darul Aman, Malaysia \\ *Department of Accounting, Faculty of Social \& Management Sciences, Kaduna State University, Nigeria \\ Email: ayubaaugustine@yahoo.com
}

Natrah Saad

School of Accountancy, College of Business, Universiti Utara Malaysia, 06010 UUM Sintok, Kedah Darul Aman, Malaysia

Zaimah Zainol Ariffin

School of Accountancy, College of Business, Universiti Utara Malaysia, 06010 UUM Sintok, Kedah Darul Aman, Malaysia

\author{
Doi:10.5901/mjss.2016.v7n1p402
}

Abstract

Tax compliance has been an issue for policy makers all over the world. Even though, few studies have considered the influence of economic factors on tax compliance, they have reported mixed findings. Therefore a moderating construct is suggested. As such, the main objective of this study is to propose the inclusion of the moderating role of perceived corruption on the relationship between economic factors and tax compliance behaviour among the Nigerian SMEs. If the proposed model is validated, the research will be useful to government, practitioners, states internal revenue service's and other regulatory authorities for policy formulations and evaluation.

Keywords: Nigerian SMEs; tax compliance; economic factors; perceived corruption.

\section{Introduction}

Achieving high level of tax compliance and maintaining the current compliance rates are issues of concern to fiscal policy makers be it in a developed, emerging or developing economies. The fundamental objective of taxation regardless of the nature of the economy is to raise revenue in order to finance its infrastructural deficit (Cheunjit, 2014). Therefore, tax compliance has begun to be a bone of contention for policy makers all over the world. Many scholars have actually dwelled on the issue, but emphasis was laid on why people and entities evade their taxes, rather than why remarkable number of people do willingly comply with their tax obligations (Slemrod, 1992). As such, it is a known fact that the impending issues of tax compliance cut across international borders. For instance, the BBC news magazine (2013) statistically revealed that, the United Kingdom (UK) government lost a huge amount of billions which were traced to the business activities of Amazon, Google and Starbucks units in the UK. According to the statistics, the companies which made a sale of 3.35 billion and 395 million UK pounds only paid 1.8 million and 6 million UK pounds as tax. While Starbucks unit recorded a turnover of 400 million, but engaged in transfer pricing with a sister company in New Zealand. Similarly, in Malaysia, statistics made available by the New Sabah Times English (2013) showed that, Inland Revenue Board Malaysia were able to solve only 1.9 million cases of tax litigations in 2012, which enabled the government to recoup RM2.95 million.

In Nigeria, the issue of tax compliance has become a serious concern. Even though adequate mechanisms in terms of tax audit tribunal, tax audits and investigation department, especially in almost all the State Internal Revenue Service (SIRS) are already in place so as to increase the level of tax compliance, low level of compliance is still recorded among the Small and Medium Enterprises (SMEs) (Taiwo, 2013). Atawodi and Ojeka (2012) reported that the tax compliance issue would remain a heinous task to achieve. Many indexes also showed that Nigeria as a country has been on the page of bottom rungs of global indexes of economic and social development. Among these latest indexes are, "Paying Taxes (2014)", the index, which annually compares tax systems across the world. In 2009, 2010, 2011, 2012, 2013 and 2014 , Nigeria was ranked $132^{\text {th }}, 180^{\text {th }}, 138^{\text {th }}, 155^{\text {th }}, 170^{\text {th }}$, and $179^{\text {th }}$ out of 189 countries. According to the 
ranking Nigeria is better than only a few countries in relation to the years of observation which was based on three major indicators, namely; total tax rate, number of payments and compliance time. In addition, the statistics further revealed that the country's tax administration was ranked better than only 10 countries in relation to 189 countries surveyed at the end of 2014. Furthermore, a growing number of reports have shown that, issues of tax compliance are increasing. For instance, Tanko (2014), reported that, Kaduna state government alone lost over N18 billion (\$112.5 million) in 2013 in unpaid taxes. This act culminated in the closure of 25 private schools, hospitals, eateries, hotels and even some micro finance banks over tax issues. In the same vein, Shekari (2014) further reiterated that, out of the six (6) million taxable residents in the state, only 500,000 pay their taxes.

In the literature, there are several studies on the relationship between factors that influenced tax and or a combination of other factors on tax compliance behavior. Some of the economic factors that have received empirical attention in relation to tax compliance over the years include tax rates, the probability of detection, and tax complexity (e.g. Allingham \& Sandmo, 1972; Alm, 2013; Becker, 1968; Fischer, Wartick, \& Mark, 1992; Manaf, Hasseldine, \& Hodges, 2005; Mustafa, 1997; Nur - tegin, 2008; Palil, Akir, \& Fadillah, 2013; Palil \& Mustapha, 2011; Saad, 2014; Torgler, 2005). Similarly, perceived corruption has also proven to be an important factor that influenced tax compliance behavior (Schneider \& Torgler, 2007; Torgler, 2003). Despite the numerous studies conducted on these factors unfortunately some of the findings were varied, mixed and weak, thus inconclusive (Eisenhauer, 2008; Slemrod, Blumenthal, \& Christian, 2001; Young, 1994).

There is actually a dearth of empirical research on the phenomenon of tax compliance in the Nigerian setting, except for few studies, such as Alabede, Ariffin and Kamil (2012) who studied the factors influencing tax compliance behaviour in Nigeria. However, in that study, the scope was tilted to the taxpayers of the Federal Capital Territory (FCT), thence did not cover the Nigerian SMEs. Similarly, Atawodi and Ojeka (2012) also studied the factors influencing tax compliance behaviour of SMEs taxpayers in the North - Central Nigeria, but the scope was limited to SMEs taxpayers of a single local government (i.e. Zaria). In spite of these aforementioned empirical studies, however, it is surprising that, presently, there is barely an empirical study that conceptualizes and proposes the moderating role of perceived corruption on the relationship between tax rate, the probability of detection, and tax complexity and tax compliance behaviour of SMEs owners/managers in the literature. The inclusion of these variables is in line with the recommendation for studying more psychological and other economic factors that may help in explaining the puzzle of tax compliance (Stefura, 2011, 2012). Further, the understanding of the effects of these constructs will be important to the government, the academia, and the practitioners, which will assist in policy formulation towards achieving the country's vision 20:2020. In addition, the research will add to the existing literature on tax compliance by developing a new model focusing on Nigerian SMEs.

Finally, in proposing the potential effect of perceived corruption, this paper offers theoretical justification for the role of perceived corruption in moderating the relationship between economic factors and tax compliance behaviour. The paper also contends that even if there have been previous works conducted on the influence of economic factors on tax compliance behavior, the findings are inconclusive, suggesting that a moderator may likely help in explaining the relationship. The remainder of the paper will be organized as follows. The next section reviews related literature, including social exchange theory, tax compliance, tax rate, the probability of detection, tax complexity and perceived corruption. This is followed by a proposed theoretical framework, while the final section concludes the paper.

\section{Review of Related Literature}

\subsection{Tax compliance}

Tax compliance in its simplest form can be seen in terms of the magnitude to which taxpayers' comply with the tax law and regulations. Therefore, the concept and meaning of tax compliance can be viewed as a phenomenon that changes over time. According to James and Alley (2004), tax compliance could be categorized into two approaches, i.e. The traditional narrow law enforcement, to the wider economic perspectives and through the more comprehensive approach relating to taxpayer decisions to conform to the wider objectives of the society as reflected in the tax policy. Intrinsically, the meaning of tax compliance has been defined in so many ways. For instance, Song and Yarbrough (1978) in a simple term, defined tax compliance as the taxpayers' ability and willingness to comply with the relevant tax laws and regulations, which are determined by ethics, legal environment and other factors at a given time and place.

Over the years, tax authorities and multinational organizations are not left out in suggesting a similar and appropriate definition for tax compliance. The Inland Revenue Board (IRB) (2009); and Australian Tax Office (ATO) (2009) separately defined tax compliance as taxpayers' ability and willingness to obey the tax laws, declare their actual income annually and pay the right amount of taxes on the due date. The Organization for Economic Co-operation and 
Development (OECD) (2001), on the other hand, outlined two categorization for the definition of tax compliance, i.e. Technical compliance and administrative compliance. According to their findings, technical compliance has to do with the technical requirement of tax laws in the computation of tax liability, whereas administrative compliance is always in line with the combination of reporting compliance, procedural compliance as well as regulatory compliance. In short, it is generally concerned with complying with the rules relating to lodging and payment of tax. Therefore, compliance is enforced on taxpayers that were unable to pay taxes through the use of other mechanisms such as; threat and application of audit and penalties (OECD, 2001). Notwithstanding this, Roth, Scholz, and Witte (1989) defined tax compliance, as the ability to comply with the reporting requirements, which invariably means that, the entity files all required tax returns at the proper time, and the returns accurately report tax liability in accordance with the internal revenue code, regulations and court decisions applicable at the time the returns are filed. An alternative to this definition has been offered by James and Alley (2002) which defined tax compliance as the ability of taxable entities to respond in relation to the spirit as well as the letter of relevant tax laws without the administration or application of enforcement. They consider tax compliance in terms of the tax gap, i.e. The difference between the true entity's income tax liability and that which is finally collected by either voluntary payment or by enforcement.

There are also few studies that viewed tax compliance from another dimension. For instance, McBarnet (2003) perceived tax compliance in three dimensions, namely (i) committed compliance, which has to do with the taxpayers' willingness and ability to pay his/her taxes without grudges; (ii) capitulative compliance, willingness to give in and pay taxes and (iii) creative compliance which is an engagement to reduce taxes by taking advantage of possibilities to redefine income and deduct expenditures within the bracket of tax laws. Hence, tax compliance is defined as the willingness of the taxpayers to abide by the tax laws, declare the correct income, claim the correct deductions, relief and rebates and pay all taxes on time (Palil \& Mustapha, 2011). Recently, Geibart (2014) conceived tax compliance as a means of navigating a maze of rules, regulations, exceptions and exemptions, which can leave a tax agent confused, disorientated and often lost when they reach a frustrating dead end.

It is of interest to note from the above definitions on the usage of some keywords which accompanied their individual or collective assumption, such as 'willingness', ability to pay, obey, act of filing tax returns, declares the correct amount, reporting all income, right amount of tax and timeliness. To the researchers' knowledge, none of the above definitions borrowed the word "appropriate authority or jurisdiction", because in Nigeria, there are three jurisdictional authority (i.e. Local, State, and Federal government) saddle with the powers to collect taxes un - behalf of the government. Virtually without identifying the appropriate authority or jurisdiction where the taxpayer supposed to pay his / her taxes, may absolutely result to noncompliance even if the taxpayer has wrongfully complied. Subject to the above discussion, and considering the context in which the study is going to be conducted, thus in the context of this study; tax compliance is defined as the taxpayers' ability and willingness to obey the tax laws, declare their actual income and pay the right amount of taxes on due date to the appropriate relevant authority or jurisdiction.

\subsection{Tax Rate and Tax Compliance}

In the literature, it has been established that the relationship between tax rates and tax compliance is directly proportional, that is an increase in the tax rates always leads to an increase in tax compliance (Allingham \& Sandmo, 1972; Hai \& See, 2011). In the same vein, Alm, Jackson, and McKee (1992b) contended that, the probability of under reporting is positively related to the tax rate. Alm, Sanchez, and De - Juan (1995) further showed that, higher tax rate may decrease tax evasion, which invariably increases the compliance level. Furthermore, Yitzhaki (1974) also revealed that tax rates have a negative effect on tax evasion, such that, an increase in tax rate makes taxpayers' more truthfully in declaring their income. On the contrary, Clotfelter (1983); Slemrod (1985); Porcano (1988); Pommerehne and WeckHannemann, (1996), in a separate but related study indicated that increasing rates of tax may result in a decrease in the level of compliance. In the same vein, Chau and Leung (2009), and Mas'ud, Aliyu, and Gambo (2014) found that a negative relationship exists between tax rates and tax compliance.

In sum, Alm et al. (1995), and Feinstein (1991) found a negative relationship between tax rates and tax compliance. More evidence revealed a high tax rate to be positively related to tax evasion as well as negatively related to tax compliance (Ali, Cecil, \& Knoblett, 2001; Christian \& Gupta, 1993). Modugu, Eragbhe, and Izedonmi (2012) and Richardson (2006) recently showed that tax rate does predict positive or negative relationship on tax compliance. Though a quite number of research conceived that higher tax rate is negatively related to tax evasion and positively related to tax compliance, other studies revealed either no relationship or negative relationship between tax rates and tax compliance. In line with Freire - Seren and Panades' contention (2013) that there is a need for further research in this direction, and coupled with the fact that the relationship between tax rates and tax compliance appears to be mixed as pointed in the 
literature, the following hypothesis are offered:

$\mathrm{H} 1$ : There is a significant relationship between tax rates and tax compliance behaviour.

\subsection{Probability of Detection and Tax Compliance}

Several researchers emphasised on the chances of being detected in various perspectives. As such, Carnes and Englebrecht (1995) emphasised on perceived detection risk, whereas the proponents of Allingham and Sandmo model (1972) as well as the proponent of the Fischer's model (1992), laid more emphasis on the probability of detection as a guilty of noncompliance (Bosco \& Mittone, 1997). Considering the relevant argument as documented by previous authors, the most encompassing and conclusive definition is well documented by Fischer et al. (1992), as the probability that noncompliance will be discovered which the Inland Revenue Services will seek to rectify the deviation.

Even though there are several empirical researches linking the probability of detection and tax compliance behaviour, the findings were mixed and inconclusive. However, Carnes and Englebrecht (1995); Eisenhauer (2008); Lewis, Carrera, Cullis, and Jones (2009) perceived the risk of being detected to be positively related with tax compliance. When the probability of being detected is high, tax compliance may also be high (Alm, 1991). On the other hand, Slemrod et al. (2001); and Young (1994) separately revealed that the probability of being detected was negatively correlated with compliance behaviour. It is glaring that there is no clear cut of argument pertaining the extant literature, but detection probability is expected to influence taxpayers' compliance behaviour, either negatively or positively. Thence, Slemrod (1985) found the nature of the relationship between detection probability and tax compliance to be vague. Since, the relationship between probability of detection and tax compliance behaviour was found to be mixed in the literature. Hence, the present study proposes the following:

$\mathrm{H} 2$ : There is a significant relationship between the probability of detection and tax compliance behaviour

\subsection{Tax Complexity and Tax Compliance}

Complexity does arise when the relevant tax authorities try to improve the equity of the tax system and, at the same time, reduce its ambiguity (McKerchar, Ingraham, \& Karlinsky, 2005). Therefore, findings regarding this construct appeared to be mixed in the literature. In particular, McKerchar (2003) claimed that, both monetary and non-monetary cost may be influenced by a corresponding increase in complexity, thereby causing a negative impact on the taxpayers' perception of fairness, as well as their respective commitment to comply.

To reiterate further, Cox and Eger (2006) who focused on the State Road Funds in the US State of Kentucky claimed that procedural tax complexity contributes to an increase in tax noncompliance. In the same vein, Gambo, Mas'ud, Nasidi, and Oyewole (2014) who studied the relationship between tax complexity and tax compliance in Africa under the self-assessment regime discovered a statistically significant negative relationship between tax complexity and tax compliance. Conversely, Kirchler, Niemirowski and Wearing (2006) found a positive relationship between tax complexity and tax compliance. Meanwhile, Forest and Sheffrin (2002) failed to discover the influence of complexity on taxpayers' perception towards fairness and compliance. Aligning to equity theory, Fjeldstad, Sjursen, and Ali (2012) stated that when the tax system is perceived to be complex, taxpayers may stand to question its fairness. As such, the more complex a tax system is, the more taxpayers perceive the inequity of the whole system. Thus, based on the theoretical justification, tax complexity may portray some level of negativity on tax compliance behaviour. As a result, when the tax system is found to be complex or cumbersome, taxpayers may perceive the lack of equity in the system which may result in low compliance. Hence, the following proposition is offered:

$\mathrm{H} 3$ : There is a significant negative relationship between tax complexity and tax compliance behaviour.

\subsection{Perceived corruption As Potential Moderator}

Evidences on the potential effects of either economic or psychological factors on tax compliance behaviour remains inconclusive. For instance the following researches discovered varied findings on the tax rates (e.g. Allingham \& Sandmo, 1972; Alm et al., 1992; Barbuta - Misu, 2011; Chau \& Leung, 2009; Clotfelter, 1983; Feinstein, 1991; Pommerehne \& Weck-Hannemann, 1996; Porcano 1988), probability of detection (Allingham \& Sandmo, 1972 ; Alm et al., 2004; Cummings et al., 2009; Kirchler, 2007; Palil \& Mustapha, 2011; Slemrod et al., 2001; Stefura, 2012) and tax complexity (Forest \& Sheffrin, 2002; McKerchar, 2003; \& Saad, 2014; Sawyer, 2007), all reported mixed results.

On the basis of inconsistent findings reported on the relationship between economic factors and tax compliance, it appears that a moderator needs to be introduced as suggested in the literature (Baron \& Kenny, 1986). Even though 
Cuccia (1994) discussed the effects of noneconomic factors (for instance perceived corruption) and other contextual features, he affirmed that they may moderate the influence of economic models. To reiterate further, Rahmani and Fallahi (2012) claimed that if a country is characterized by less corruption, tax compliance may improve as well as the willingness to pay taxes, which invariably means that, high level of corruption may affect tax compliance and willingness to pay taxes negatively. Aligning to social exchange theory, relationship is absolutely built on the basis of trust, and for it to continue or survive, it must be beneficial to all parties (Blau, 1964; Homan, 1974). Therefore, if the taxpayers' perceived the government to be corrupt, that is the least amount of tax paid is not judiciously utilized in the form of service provision, the taxpayers' may feel being cheated and may in turn affect his / her compliance behaviour. Hence, this paper proposes that perceived corruption has the potential to contribute to a better understanding of the conflicting findings concerning the relationship between economic factors (tax rates, the probability of detection, and tax complexity) and tax compliance behaviour. Furthermore, this paper argues that the strength of the relationship between economic factors and tax compliance may be affected if the taxpayers perceived the system to be unfair and untruthful. Hence, in line with these arguments and evidences, it is reasonable to argue that, the level of corruption being perceived by the taxpayers may influence their behaviour irrespective of whether the tax rates are high, or the probability of detection are certain or not, or the complexity of the tax system is also high or not. Additionally, despite the justification for the above phenomenon, relatively little is known about the moderating role of perceived corruption of the relationship between economic factors and tax compliance behaviour. In essence, economic factors alone may not be sufficient in explaining the puzzle of tax compliance, a blend of both economic and a psychological factor (perceived corruption) may offer a reasonable explanation to the puzzle of tax compliance. Hence, the following proposition is offered:

H4: Perceived corruption will moderate the relationship between economic factors (tax rate, the probability of detection, and tax complexity) and tax compliance behaviour.

\section{Proposed Research Framework}

Building on the above empirical evidences and research problem, a proposed research framework for this study has been developed and depicted in Figure1. Therefore, the main objective of this study is to propose the moderating role of perceived corruption on the relationship between economic factors (tax rate, the probability of detection, and tax complexity) and tax compliance behaviour in relation to Nigerian SMEs owners /managers.

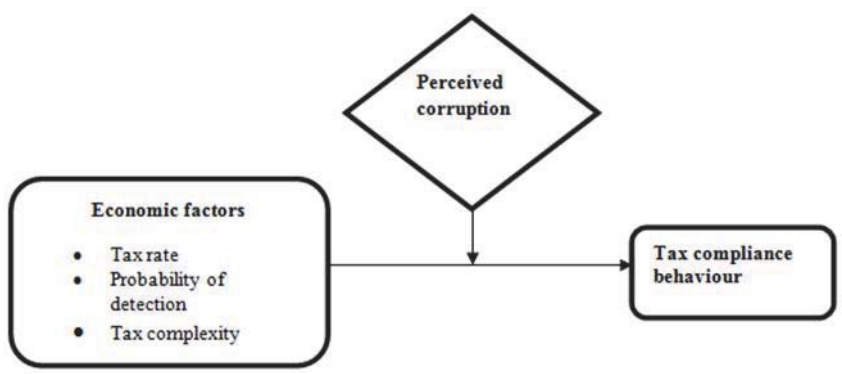

Figure 1: Proposed Research Framework

The proposed research framework as depicted in Figure 1 shows the moderating role of perceived corruption on the relationship between economic factors (tax rate, the probability of detection, and tax complexity) and tax compliance behaviour. As empirically revealed, economic factors may affect the compliance behaviour of SME taxpayers. However, it is also postulated that economic factors alone may be insufficient in explaining the puzzle of tax compliance. Hence, whether economic factors or psychological factor (perceived corruption) will be effective in explaining the tax compliance behaviour of SMEs taxpayers may depend on the degree of service provision provided by the relevant tax authorities to the individual or collective taxpayers. When those public goods are not in place, the taxpayers may perceive the system to be corrupt and vice versa, which in turn may affect the likelihood of compliance. 


\section{Conclusion}

In this study, we have presented a model for the potential moderating effect of perceived corruption on the relationship between economic factors and tax compliance behaviour as depicted in Figure 1. The proposed model has several critical implications for unveiling and understanding the factors that may influence the behaviour of SMEs taxpayers. These will be useful to all. Specifically, if the proposed framework is validated, the research in the future will adopt a positivist approach in the process of data collection and the findings will provide important insight to policy makers, practitioners, academicians, states internal revenue services, and other regulatory authorities in policy formulations and evaluation. Furthermore, the findings will have practical implications towards achieving the Nigeria's vision 20:2020 and beyond.

\section{References}

Alabede, J. O., Ariffin, Z.Z., \& Kamil, I. (2011). Public governance quality and tax compliance behavior in Nigeria : The moderating role of financial condition and risk preference. Issues in Social and Environmental Accounting, 5(1/2), 3-24.

Ali, M. M., Cecil, H. W., \& Knoblett, J. A. (2001). The effects of tax rates and enforcement policies on taxpayer compliance: A study of self-employed taxpayers. Atlantic Economic Journal, 29(2), 186-202.

Allingham, M., \& Sandmo, A. (1972). Income tax evasion: A theoretical analysis. Journal of Public Economics, 1(3-4), 323-338.

Alm, J. (1991). A perspective on the experimental analysis of taxpayer reporting. Accounting Review, 66(3), 577- 593.

Alm, J. (2013). Expanding the theory of tax compliance from individual to group motivations ( No. 1309) (pp. 1 - 24). New Orleans.

Alm, J., Jackson, B., \& McKee, M. (1992b). Estimating the determinants of taxpayer compliance with experimental-data. National Tax Journal, 45(1), 107-114.

Alm, J., Sanchez, I., \& De Juan, A. (1995). Economic and noneconomic factors in tax compliance. Kyklos, 48(1), 3-18.

Atawodi, O. W., \& Ojeka, S. A. (2012). Factors that affect tax compliance among small and medium enterprises in North Central Nigeria. International Journal of Business and Management, 7(12), 87-96. doi:10.5539/ijbm.v7n12p87.

Australian Tax Office (2009). Retrieved 22 May, 2014, from http://www.ato.gov.au/corporate/content.asp?doc=/content/00107941.htm.

Barbuta - Misu, N. (2011). A review of factors for tax compliance. Economics and Applied Informatics, 1(1), 69 - 76.

BBC NEWS (May 21, 2013), Google, Amazon, Starbucks: The Rise of 'Tax Shaming' http://www.bbc.co.uk/news/magazine-20560359.

Becker, G. S. (1968). Crime and punishment: An economic approach. Journal of Political Economy, 76(2), 168-217.

Blau, P. M. (1964). Exchange and power in social life. New York: John Wiley \& Sons, Inc.

Bosco, L., \& Mittone, L. (1997).Tax evasion and moral constraints: Some experimental evidence. KYKLOS, 50, 297-324.

Carnes, G. A., \& Cuccia, A. D. (1996). An analysis of the effect of tax complexity and its perceived justification on equity judgments. The Journal of the American Taxation Association, 18(2), 40-56.

Carnes, G. A., \& Englebrecht, T.D. (1995, Spring). An Investigation of the Effect of Detection Risk Perceptions, Penalty Sanctions, and Income Visibility on Tax Compliance. The Journal of the American Taxation Association, 17(1), 26-41.

Chau, G., \& Leung, P. (2009). A critical review of Fischer tax compliance model: A research synthesis. Journal of Accounting and Taxation, 1, 034-040.

Cheunjit, P. (2014). The culture of taxation: Denition and conceptual approaches for tax administration. Journal of Population and Social Studies, 22(1), 14 - 34. deoi: 10.14456/jpss.2014.4.

Christensen, A.L., Weihrich, S.G., \& Gerbing, M.D. (1994). The impact of education on perceptions of tax fairness, Advances in Taxation, 6, 63-94.

Christian, C. W., \& Gupta, S. (1993). New evidence on 'secondary evasion. The Journal of the American Taxation Association, 15(1), 7293.

Clotfelter, C. T. (1983). Tax evasion and tax rates: An analysis of individual returns. Review of Economics and Statistics 65 (3), 363-373.

Cox, S. P. \& Eger, R. J. I. (2006). Procedural complexity of tax administration: The road fund case. Journal of Public Budgeting, Accounting and Financial Management, 18(3), $259-283$.

Cummings, R.G., Martinez - Vazquez, J., McKee, M., \& Torgler, B. (2009). Tax morale affects tax compliance: Evidence from surveys and an art factual field experiment. Journal of Economic Behaviour \& Organisation, 70(3), 447 - 457.

Eisenhauer, J. G. (2008). Ethical preferences, risk aversion, and taxpayer behaviour. The Journal of Socio-Economics, 37(1), 45-63.

Feinstein, J. S. (1991). An econometric analysis of income tax evasion and its detection. The RAND Journal of Economics, 22(1), 14. Doi: $10.2307 / 2601005$.

Fischer, C.M., Wartick, M., \& Mark, M. M. (1992). Detection probability and taxpayer compliance: A review of the literature. Journal of Accounting Literature, 11, 1-27.

Fjeldstad, O. H., Sjursen, I. H., \& Ali, M. (2012). Factors affecting tax compliant attitude in Africa: Evidence from Kenya, Tanzania, Uganda and South Africa. Presented at: Centre for the Study of African Economies (CSAE) Conference (Vol. 18).

Forest, A., \& Sheffrin, S.M. (2002). Complexity and compliance: An empirical investigation. National Tax Journal, 55, 75 - 88.

Freire-Serén, M. J., \& Panadés, J. (2013). Do higher tax rates encourage/discourage tax compliance? Modern Economy, 4, 809 - 817.

Gambo, E.J., Mas'ud, A., Nasidi, M., \& Oyewole, O.S. (2014). Tax complexity and tax compliance in African self-assessment environment. International Journal of Management Research \& Review, 4(5), 575 - 582. 
Geibart, N. (2014). Digging out the complexities of tax compliance. The Business, 32 - 33.

Hai, O. T., \& See, L. M. (2011). Behavioural intention of tax non-compliance among sole-proprietors in Malaysia. International Journal of Business and Social Science, 2(6), 142-152.

Homan, G. C. (1974). Social behaviour: Its elementary forms. New York: Harcourt Brace Jovanovich.

Inland Revenue Board (IRB) Malaysia (2009).Retrieved 22 May 2014, from http://www.hasil.gov.my.

James, S., \& Alley, C. (2002). Tax compliance, self-assessment system and tax administration. Journal of Finance, and Management in Public Services, 2(2), $27-42$.

James, S., \& Alley, C. (2004). Tax compliance, self-assessment and tax administration. Journal of Finance and Management in Public Services, 2(2), $27-42$.

Kirchler, E., Niemirowski, A., \& Wearing, A. (2006). Shared subjective views, intent to cooperate and tax compliance: Similarities between Australian taxpayers and tax officers. Journal of economic psychology, 27(4), 502-517.

Lewis, A., Carrera, S., Cullis, J., \& Jones, P. (2009). Individual, cognitive and cultural differences in tax compliance. UK and Italy compared. Journal of Economic Psychology, 30, 431-445.

Manaf, N. A., Hasseldine, J., \& Hodges, R. (2005). The determinants of Malaysian land taxpayers' compliance attitude. eJournal of Tax Research, 3(2), 206-221.

Mas'ud, A., Aliyu, A.A., \& Gambo, E.J. (2014) Tax rate and tax compliance in Africa. European Journal of Accounting Auditing and Finance Research, 2(3), 22 - 30.

McBarnett, D. (2003). When compliance is not the solution but the problem: From changes in law to changes in attitude. In V. Braithwaite, Tax democracy: Understanding tax avoidance and evasion. Aldershort: Ashgate Publishing Ltd.

McKerchar, M. (2003). The impact of complexity upon tax compliance: A study of Australian personal taxpayers. Australian Tax Research Foundation.

McKerchar, M., Ingraham, L R., \& Karlinsky, S. (2005).Tax complexity and small business: A comparison of the perceptions of tax agents in the United States and Australia. Journal of Australian Taxation, 289-327.

Modugu, P. K., Eragbhe, E., \& Izedonmi, F. (2012). Government accountability and voluntary tax compliance in Nigeria. Research Journal of Finance and Accounting, 3 (5), $69-76$.

Mustafa, H. H. (1997). An evaluation of the Malaysian tax administrative system and taxpayers' perceptions towards self-assessment system, tax law fairness and tax law complexity. Unpublished manuscript, Universiti Utara Malaysia, Malaysia.

New Sabah Times English (2013, July, 20). IRB solves nearly 1.9 mil tax evasion cases in 2012.

Nur-tegin, K. D. (2008). Determinants of business tax compliance. The B.E. Journal of Economic Analysis \& Policy, 8(1), $1-26$. doi:10.2202/1935-1682.1683.

OECD. (2010). Survey of trends and developments in the use of electronic services for Taxpayer Service Delivery, http://www.oecd.org/ dataoecd/20/49/45035933.pdf(AccessDate 12-11-2014).

Palil, M. R., \& Mustapha, A. F. (2011). Factors affecting tax compliance behaviour in self assessment system. African Journal of Business Management, 5(33), 12864-12872. doi:10.5897/AJBM11.1742.

Palil, M.R., Akir, M.R.,\& Fadillah, W. (2013). The perception of taxpayers on tax knowledge and tax education with level of tax compliance: A study of the influences of religiosity. Asean Journal of Economics, Management and Accounting, 1, 118 - 129.

Paying Taxes. (2014). The global picture. A comparison of tax systems in 189 economies worldwide.

Pommerehne, W. W., \& Weck-Hannemann, H. (1996). Tax rates, tax administration and income tax evasion in Switzerland. Public Choice, 88(1-2), 161-170.

Porcano, T. M. (1988). Correlates of tax evasion. Journal of Economic Psychology, 9(1), 47-67.

Rahmani, T., \& Fallahi, M.A. (2012). Corruption, democracy and tax compliance: cross-country evidence. The Business \& Management Review,2 (2), 221 - 230.

Richardson, G. (2006). Determinants of tax evasion: A cross-country investigation. Journal of International Accounting, Auditing and Taxation, 15(2), 150-169. doi:10.1016/j.intaccaudtax.2006.08.005.

Roth., J. A., Scholz, J.T., \& Dry-Witte, J. T. (1989). Taxpayer compliance: An agenda for research, volume1. Philadelphia: University of Pennsylvania Press.

Saad, N. (2014). Tax knowledge, tax complexity and tax compliance: Taxpayers' view. Procedia Social and Behavioral Sciences, 109(1), 1069-1075. doi:10.1016/j.sbspro.2013.12.590.

Sawyer, A. (2007). New Zealand's tax rewrite program - in pursuit of the (elusive) goal of simplicity. British Tax Review, 4, 405 - 427.

Schneider, F. \& Torgler, B. (2007). The impact of tax morale and institutional quality on the shadow economy. CESifo Working Paper Series, 1899.

Shekari, I. (2014, April 14). Tax evasion in Kaduna state. Premium Times.

Slemrod, J. (1985). An empirical test for tax evasion. Review of Economics and Statistics, 67(2), 232-238.

Slemrod, J. (1992). Why people pay taxes, tax compliance and enforcement. Ann Arbor: University of Michigan Press.

Slemrod, J., Blumenthal, M., \& Christian, C. (2001). Taxpayer response to an increased probability of audit: Evidence from a controlled experiment in Minnesota. Journal of Public Economics, 79(3), 455-483. doi:10.1016/S0047-2727(99)00107-3.

Song, Y.D., \& Yarbrough, T.E. (1978). Tax ethics and taxpayer attitudes: A survey. Public Administration Review, 38(5), $442-452$.

Stefura, G. (2011). The role played by economic and non-economic variables in the analysis of tax compliance. Review of Economic and Business Studies, 4(2), 105- 120.

Stefura, G. (2012). A new perspective on individual tax compliance: The role of the income source, audit probability and the chance of 
being detected. The USV Annals of Economics and Public Administration, $12(2$ (16)), $192-201$.

Taiwo, O. (2013). Services, R., International, P., Council, N. E., Academy, P. T., \& Faculty, D. T. (2013). An interview with Taiwo Oyedele on the tax implications of Nigeria's rebased GDP, (May).

Tanko, M. (2014, June 18). Kaduna shuts 25 private schools, MFB over tax evasion, Punch.

Torgler, B. (2003). Tax morale in Latin America. Paper presented at the Third International Research Conference Responsive Regulation: International Perspectives on Taxation.

Torgler, B. (2005). Speaking to theorists and searching for facts: Tax morale and tax compliance in experiments. Journal of Economic Surveys, $16(5), 77-89$.

Yitzhaki, S. (1974). Income tax evasion: A theoretical analysis. Journal of public economics, 3(2), 201-202.

Young, J.C. (1994). Factors associated with non-compliance: Evidence from the Michigan tax amnesty program. Journal of American Taxation Association, 16(2), 82-105. 